\title{
DISERTACIÓN EN EL ACTO CONMEMORATIVO DE LOS 40 AÑOS DE PRUDENTIA IURIS, 5 DE OCTUBRE DE 2020
}

\author{
Félix A. Lamas ${ }^{1}$
}

Para citar este artículo: Lamas, F. A. (2020). "Disertación en el acto conmemorativo de los 40 años de Prudentia Iuris". Prudentia Iuris, N. 90, pp. 223-226 DOI: https://doi.org/10.46553/prudentia.90.2020.pp.223-226

\section{Proemio}

Es un honor para mí, un viejo profesor, más antiguo en esta universidad que Prudentia Iuris, que se me haya invitado a participar en esta celebración, y que he aceptado no sólo en mi carácter de Profesor Emérito sino también como miembro del Comité Científico de la revista. Lo hago con la alegría de hablar entre amigos que comparten un común ideario y el amor a la Universidad Católica Argentina, a esta facultad, y a la Iglesia.

En ocasión de conmemorar 40 años de vida fructífera de Prudentia Iuris, parece adecuado y oportuno reflexionar sobre su cometido, es decir, su función y finalidad en el ámbito de la Facultad de Derecho, la Universidad Argentina y la Santa Iglesia Católica, y sobre su concreta identidad, teniendo en cuenta que se trata de un órgano principal de expresión de la vida académica y científica. A mi entender, ella y el Doctorado deben ser el punto más alto y representativo de nuestra facultad.

1 Profesor Emérito de la Pontificia Universidad Católica Argentina, Buenos Aires, Argentina. Correo electrónico: felixlamas@uca.edu.ar. 


\section{La identidad esencial de Prudentia Iuris}

En este punto no caben dudas ni titubeos. Su perfil está definido por su acto fundacional, debido a ese gran hombre -y, en mi caso, gran amigo- que fuera Santiago de Estrada. Y, además y sobre todo, por la índole católica de la Universidad, la recta Filosofía, la Sagrada Teología, el Magisterio de la Iglesia y la Tradición Apostólica.

De acuerdo con lo anterior, su función esencial podría resumirse así:

1. Es y debe ser órgano de expresión de la Verdad sapiencial del Derecho como ciencia subordinada a los saberes universales, la Sagrada Teología y la Filosofía Primera, y siempre sujeta al criterio rectificador del Magisterio de la Iglesia y la Tradición Apostólica. Esto implica, en nuestro ámbito específico, ser instrumento de esclarecimiento, difusión y defensa de los principios de la ley y el Derecho Naturales, que son los que permiten al conocimiento jurídico constituirse en verdadera Scientia iuris. Por otra parte, si se considera al Derecho vivido como prudentia iuris, no debe olvidarse que lo que Santo Tomás de Aquino llamaba intellectus y Aristóteles noûs, como hábitos de los primeros principios, son parte integrales de la prudencia. De modo que no hay auténtica prudentia iuris sin la iluminación de los principios.

2. El Derecho, como ciencia práctica, está subalternada a los principios de la Antropología. Por esta razón, la fuente ontológica de los saberes jurídicos y de sus principios, de los que Prudentia Iuris es instrumento de expresión y defensa, es la naturaleza específica del hombre como espíritu encarnado.

3. Prudentia Iuris fue creada con la idea de inscribirse como órgano académico de la tradición clásica y tomista, según los documentos fundacionales de la Universidad. Y ese fue su itinerario, en continuación de una notable fidelidad activa y creativa de lo que más de una vez el Decano Herrera denominara la tradición académica de nuestra facultad. Tradición de la que nos honramos y que fuera lúcidamente continuada por todas las autoridades de esta facultad, hasta nuestros días.

4. Fue, desde sus orígenes, órgano y estímulo de la investigación, función que se ha ido incrementando e intensificando, alcanzando resultados de alto valor científico y que nos orgullecen a todos los miembros de la comunidad universitaria. Esto, claro está, depende de las políticas en esta materia de la Universidad y, además, está limitado por las restricciones presupuestarias.

5. Nuestra revista es y debe ser foro de la comunicación y discusión 
científica según un sano pluralismo académico, que permita insertarse en la comunidad científica universal, pero sin perder su propia identidad constituida radicalmente por sus principios. Y en esa misma línea, se constituye en instrumento bibliográfico docente que permite la participación de los alumnos en la alta tarea de investigación y discusión académica.

\section{La identidad accidental o circunstancial de Prudentia Iuris}

Pero la concreta identidad de Prudentia Iuris está enmarcada en circunstancias generales y públicas que determinan el orden de las urgencias, y que, en algunos casos, condicionan la libertad de la Universidad y afectan el diseño de su actividad.

Señalemos algunos casos:

1. La crisis moral y cultural que opera como circunstancia general de nuestra época, en la que el relativismo, el gnosticismo, el nominalismo, y las nuevas ideologías disolventes del orden natural constituyen el enemigo radical de la vigencia de los principios: soberanía de Dios, primacía del bien común, ley natural como emanación de la sabiduría divina y de la verdad inmanente de la naturaleza humana.

2. La confusión, y consiguiente ambigüedad, aun en no pocos pensadores católicos, que no disciernen con claridad la verdad de los principios, que desconocen el orden epistemológico clásico, tradicional y cristiano y que optan por una apertura al mundo actual en su descomposición, torna difícil un sano pluralismo sapiencial.

3. En este contexto epistémico, y como consecuencia del cientificismo de moda, el Derecho corre el peligro de convertirse en un instrumento de control social, o en palabras de Francesco Gentile, en una "Geometría legal", que admite como principio la fuerza -expresada en la ley meramente positiva- como criterio de validez y vigencia.

4. La creciente injerencia del poder público en la vida de la universidad. Ejemplo de ello son las reglas formales que se imponen para el reconocimiento científico de la publicación y de la investigación que, aunque en algunos casos son beneficiosas, en otros pueden llegar a desnaturalizar los cometidos, funciones y finalidad de nuestra revista, imponiendo una uniformidad que responde a idearios epistémicos diversos y a veces contrarios al ideario sapiencial al que hemos aludido. 
5. Por último, deben señalarse los ataques públicos a núcleos de nuestros principios no negociables: aborto legal, destrucción de la familia y del orden natural del matrimonio, ideología de género, eutanasia, desacralización de la vida pública y del Estado, relativismo cultural como pensamiento único y obligatorio, y tanto otros que sería imposible enumerar aquí. Esta situación ha exigido y exige cotidianamente que Prudentia Iuris, como órgano de la Universidad y de la Iglesia, agregue a su tarea de iluminación científica la actitud agonal de defensa, al servicio de la Fe, de la racionalidad y de la misma vida humana.

\section{Conclusión}

Hoy es ímprobo el oficio de dirigir la Facultad de Derecho y nuestra querida Prudentia Iuris. Como siempre, pero más que nunca, requiere ejercer y hacer realidad el nombre de nuestra publicación. Es tarea de prudencia el compatibilizar con orden los distintos aspectos constitutivos de la identidad esencial de la revista. También lo es, y aún más exigente, dejar a salvo esa identidad esencial en un marco circunstancial adverso.

Y quizás, no esté de más recordar que la prudencia requiere de principios claros, de razón rectificadora de la acción y, sobre todo, de virtud moral, en especial fortaleza y justicia, transfiguradas por la gracia de Dios. 